Military Technical College Kobry Elkobbah, Cairo, Egypt.

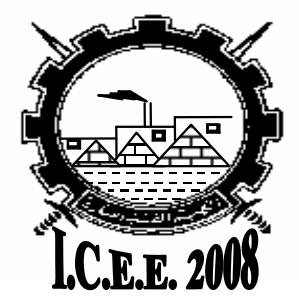

$4^{\text {th }}$ International Conference On

Chemical \& Environmental Engineering

\title{
II. ELECTRICAL PROPERTIES OF NI/SILICA GEL AND PT/ Y- ALUMINA CATALYSTS IN RELATION TO CATALYTIC ACTIVITY
}

\author{
H. M.Gobara * and M. M.Gomaa **
}

\begin{abstract}
The catalytic activity of silica gel and silica gel supported nickel (viz., 2, 5 \& 8 wt.\% $\mathrm{Ni}$ ) and $y$-alumina supported platinum (viz., 0.3 and $0.6 \mathrm{wt} \% \mathrm{Pt}$ ) was studied for $\mathrm{n}$ hexane or n-pentane cracking and cyclohexane dehydrogenation adopting pulse technique. The results showed that $\mathrm{Pt} / \mathrm{Y}$-alumina could be selective catalyst for cyclohexane dehydrogenation reaction. Ni/silica gel catalyst was a good cracking catalyst, the activity of which increased by increasing the metal content up to $8 \% \mathrm{Ni}$. For cyclohexane, dehydrogenation over Ni/silica gel the activity increased by increasing the metal loading. $\mathrm{N}_{2}$ sorption characterizations showed that both silica gel- and $Y$-alumina-supported catalyst samples exhibited mesoporous structures. Silica gel and silica gel-supported samples having the ink-bottle type pores while $\gamma$ alumina and $y$-alumina supported platinum samples having plate like type pores. BET surface area and total pore volume decreased by increasing metal loading for both catalyst samples.
\end{abstract}

Electrical properties of pure $y$-alumina and silica gel supports were functions of metal content and frequency of the applied field. The increase of the conductivity is considered as a good indicator of the decrease in the activation energy (increase of catalytic activity). The observed increase in conductivity with the increase of metal loading may be due to increase in the mobility of the free charge carriers, i.e. ions and free radicals taking part in the mechanism of catalytic conversion of hydrocarbons over the catalyst polarized active centers which increased by increasing of metal loading. These charge carriers diffuse in the bulk of pores and reach electrodes where they discharge giving rise to diffusion impedance (Warburg impedance).

\section{KEY WORDS:}

$\mathrm{Pt} / \mathrm{Y}$-alumina reforming catalyst, Ni/silica gel, electrical properties, Catalytic activity, Conductivity, Dielectric constant.

Researcher, Catalysis Department, Petroleum refining Division, Egyptian Petroleum Research Institute (EPRI), Nasr City, P.O. 11727, Cairo, Egypt.

** Researcher, Geophysical Sciences Dept., National Research Center, Dokki, Cairo, Egypt. 


\section{1- INTRODUCTION}

Nickel catalysts have been used for several years for many industrial processes, such as hydrogenation, dehydrogenation, hydrogenolysis, reforming and gas shift conversion due to its availability, high activity and selectivity [1-6], It could be a cheap substitute for plate forming catalyst either in the form of Raney nickel, or supported on different materials.

High surface area supports, usually oxides, are used extensively in industry for the preparation of metal catalysts. The traditional view of the support is that it should be passive, inert carrier, whose function is to improve the efficiency of metal catalyst by increasing the dispersion and stability of metal particles. Generally, it has emerged that the support may play a more active role [7]. Nickel catalyst may be loaded over different supports such as: silica, alumina and alumosilicates (either natural clays or synthetic zeolites).

Mesoporous alumina have widespread uses as catalyst supports, which are superior to silica because of the higher hydrolytic stability and the different point of zero charge which makes it easier to load with different metal species. However, mesoporous alumina materials had considerably less attention compared to mesostructured silica [8-12].

Silica is known to be used as a common support for nickel catalysts [13] it usually exhibits a weak interaction with the active phase. It is chemically and physically stable with high surface area and wide pores which permit metal entrance during preparation without hindering the reactions taking place over its surface [14]. Mesoporous silica containing accessible function groups has a variety of potential applications, including catalysis, sensing and separation [15].

The Electrical properties of the studied systems and related pores or channel structures have been the object of intense studies for many years. Most of the experiments on these mesoporous solids have been done by [16-17] focusing on the mobility of the exchangeable cations ( $\mathrm{Pt}$ or $\mathrm{Ni}$ ) in silica gel or $\mathrm{\gamma}-\mathrm{Al}_{2} \mathrm{O}_{3}$ supports by means of electrical methods of characterization. Such methods of characterization can be expressed in terms of the impedance $Z$ or the admittance $Y$. The admittance $Y=G+$ jwC, where $G$ is the parallel conductance of the sample $\left(\mathrm{Ohm}^{-1}\right)$, $j=\sqrt{-1}, w=2 \pi f$ ( $\mathrm{f}$ is the frequency of the applied field), and $\mathrm{C}$ is the parallel capacitance of the sample (in Farad). The impedance $Z$ is given by: $Z=R_{s}+\frac{1}{j w C_{s}}$, where $R_{S}$ and $C_{s}$ are the series resistance (in Ohm) and capacitance (in Farad), respectively. The complex conductivity $\sigma^{*}=\sigma^{\prime}+j \sigma^{\prime \prime}$, where $\sigma^{\prime}=w \varepsilon^{\prime \prime}$ and $\sigma^{\prime \prime}=w \varepsilon^{\prime}, \varepsilon^{\prime \prime}$ and $\varepsilon^{\prime}$ being the dielectric loss and dielectric constant, respectively [18]. Electrical properties are suggested for the interpretation of the mechanism of the catalytic process [19] and characterization of semiconductor catalysts. Thus Bahga and Khalil 
[20] found that the electrical conductivity of Egyptian clays is the only criterion which is in parallel with their catalytic activities more than other physical characterization.

This work is aimed at studying the relation between the electrical properties of $\mathrm{Ni} /$ silica gel and $\mathrm{Pt} / \mathrm{Y}$-alumina and their catalytic activities towards $\mathrm{n}$-paraffin ( $\mathrm{n}$ pentane or n-hexane) and cycloparaffin (cyclohexane) conversion.

\section{2-SAMPLE PREPARATION AND MEASUREMENTS}

\subsection{Catalyst preparation}

Catalysts samples were prepared by loading nickel over silica gel support (containing $2,5 \& 8 \mathrm{wt}$ \% $\mathrm{Ni}$ ) and platinum over $\mathrm{y}$-alumina support (containing 0.3 and $0.6 \mathrm{wt}$. \% $\mathrm{Pt})$ using wet impregnation technique.

Before metal impregnation, the support was treated as follows:-

i) Silica gel support (Merck) was refluxed with concentrated $\mathrm{HCl}$ solution for 45 minutes and washed several times with hot distilled water until the decant became free of chloride ion. After washing, the sample was dried at $110^{\circ} \mathrm{C}$ and calcined at $350^{\circ} \mathrm{C}$ in a stream of air for $4 \mathrm{~h}$ [21].

ii) $\mathrm{Y}-\mathrm{Al}_{2} \mathrm{O}_{3}$ (containing $\mathrm{Na}_{2} \mathrm{O}$ and $\mathrm{Fe}_{2} \mathrm{O}_{3}<0.02$ wt. \%) was supplied by Institute of Catalysis (Novisipersk, Russia) and was calcined at $450^{\circ} \mathrm{C}$ in a stream of air for $6 \mathrm{~h}$.

iii) Nickel catalysts containing 2, 5 and 8 wt. \% $\mathrm{Ni}$ were prepared using wet impregnation technique [22], by adding slowly the required amount of an aqueous solution of $\mathrm{Ni}\left(\mathrm{NO}_{3}\right)_{2} \cdot 6 \mathrm{H}_{2} \mathrm{O}$ to the silica gel support in order to obtain the desired metallic content in the final catalysts. To ensure the complete absorption the mixture was stirred vigorously for 15 minutes and dried at $110^{\circ} \mathrm{C}$ for $16 \mathrm{~h}$ according to Ciapetta technique [21]. After that, the dried sample (nickel nitrate/silica gel) was decomposed in a stream of hydrogen, at a reduction temperature of $450^{\circ} \mathrm{C}$ for $4 \mathrm{~h}$ to obtain Ni/Silica gel catalyst [23-25].

For loading Platinum, the pretreated support was impregnated with $0.002 \mathrm{M}$ solution of $\mathrm{H}_{2} \mathrm{PtCl}_{6} 6 \mathrm{H}_{2} \mathrm{O}$. Appropraite volume of impregnating solution was added to the supports in order to obtain $0.3 \& 0.6 \mathrm{wt} \% \mathrm{Pt}$ in the final catalysts. The mixture was stirred for few minutes and dried at $110^{\circ} \mathrm{C}$ for $16 \mathrm{~h}$ and calcined at $450^{\circ} \mathrm{C}$ for $2 \mathrm{~h}$. Calcination befor reduction was to remove the water molecules that were still contained in support pores and to allow the stabilization of active sites. The Pt (IV) ions become very mobile in the presence of water at higher temperature leading thereby to agglomeration of metallic Pt particles [26]. The oxide samlpes were then reduced at $350^{\circ} \mathrm{C}$ in a stream of purified dry hydrogen gas with a flow rate $100 \mathrm{ml} / \mathrm{min}$ for $4 \mathrm{~h}$. 


\subsection{Surface characteristics}

Nitrogen adsorption-desorption isotherms at liquid nitrogen temperature were obtained with a NOVA 3200, USA. Prior to analysis, samples were outgassed in vacuum at $300^{\circ} \mathrm{C}$ for $3 \mathrm{~h}$ to remove the moisture and other impurities of the samples. Brunauer Emmett and Teller (BET) surface areas $\left(\mathrm{S}_{\mathrm{BET}}\right)$ [27] were calculated from nitrogen uptakes at relative pressure (P/Po) ranging from 0.05 to 0.35 for all investigated samples. The total pore volume was derived from the amount of nitrogen adsorbed at the relative pressure close to unity by assuming that all the accessible pores had been filled with condensed nitrogen in the normal liquid state. Pore size distribution was calculated from Barrett, Joyner and Halenda (BJH) method using desorption branch of the isotherms. The desorption leg of the isotherms is preferred for pore analysis as it is thermodynamically more stable than the adsorption leg due to the lower Gibb's free energy change [28].

\subsection{Catalytic activity}

Catalytic activity of all investigated catalyst samples was tested through n-hexane and/or n-pentane cracking and cyclohexane dehydrogenation as two model reactions using a micro catalytic pulse technique. Reactants were injected in micro quantities $(2 \mu \mathrm{L})$ by micro syringe in the form of pulses into a micro reactor containing $0.25 \mathrm{gm}$ of the tested catalysts. The reactor effluent was passed through a chromatographic column for separation and determination of products using flame ionization detector connected to computerized data acquisition station. The column is $200 \mathrm{Cm}$ length and $0.3 \mathrm{Cm}$ internal diameter, containing acid washed PW chromosorb (60-80 mesh size) loaded by $15 \%$ by weight squalane. The reactions were carried out under atmospheric pressure and at temperature rang $210-480^{\circ} \mathrm{C}$. Hydrogen flow rate was kept constant at $50 \mathrm{ml} / \mathrm{min}$. Prior to catalytic activity test, the reduced catalyst samples were heated in $\mathrm{H}_{2}$ flow up to $450^{\circ} \mathrm{C}$ with a heating rate $100^{\circ} \mathrm{C} / \mathrm{h}$ and kept $2 \mathrm{~h}$ at $450^{\circ}$ $\mathrm{C}$ for their activation. Few doses of reactants were injected first to reach steady state of the activity. The chromatographic column temperature was adjusted and controlled at $50^{\circ} \mathrm{C}$.

\subsection{Electrical properties}

Electrical measurements were made on thin disk-shaped samples with different dimensions of thickness and diameter. A two electrode technique was used with electrodes (of Agilant dielectric test fixture 16451B) on the two opposite faces of the sample disk (Fig. 1). Data were collected in the frequency range from $0.1 \mathrm{~Hz}$ up to $100 \mathrm{KHz}$ at room temperature $\left(\sim 20^{\circ} \mathrm{C}\right)$ and a voltage of $1 \mathrm{~V}$ using a Hioki 3522- 50 LCR Hitester Impedance Analyzer. The samples were covered with an aluminum foil in order to enhance the contact between the sample surface and the electrode. All experimental parameters were kept constant in order to obtain comparable values. The Impedance Analyzer measured the total impedance $\left(Z_{T}\right)$ of the equivalent circuit. The total impedance $\left(Z_{T}\right)$ is the sum of two contributions in series, the impedance $Z_{C}$, which accounts for the capacitance of the cell and of the interconnecting wires, and the series impedance $Z_{L}$ of the inter-connecting system. $Z_{L}$ could be measured directly by short-circuiting the cell and $Z_{C}$ can then calculated from the difference $\left(Z_{T}-\right.$ $Z_{\text {L) }}[29-30]$. 
The series and parallel capacitance and resistance were measured at different frequencies. The complex relative dielectric constant could be written as $\varepsilon^{*}=\varepsilon^{\prime}-i \varepsilon^{\prime \prime}$, where the real part of the complex dielectric constant $\varepsilon^{\prime}=C_{p} d / \varepsilon_{0} A$ and the imaginary part $\varepsilon^{\prime \prime}=G_{p} d / w \varepsilon_{0} A$ are related to the measured parameters, A being the crosssectional area of the sample, $\mathrm{d}$ its thickness, $\varepsilon_{0}$ the permittivity of free space $\left(8.85 \times 10^{-12} \mathrm{~F} / \mathrm{m}\right), \mathrm{w}$ the angular frequency, $G_{p}$ the parallel conductance, and $C_{p}$ the parallel capacitance.

\section{3- RESULTS AND DISCUSSION}

\subsection{Surface characteristics}

The obtained isotherm for silica gel (support) showed that it is of type IV (Fig. 2), characteristic of mesoporous material [31]. H2 hysterisis loop in the range 0.4-0.8 $\mathrm{p} / \mathrm{po}$ which indicates the presence of ink-bottle type pores. The obtained adsorptiondesorption isotherms for the different silica gel supported- nickel catalysts posses almost the same behaviour as that of pure silica gel support (Fig. 2).

Upon loading with $\mathrm{Ni}$, a gradual decrease in surface area is observed up to $5 \mathrm{wt}$. $\% \mathrm{Ni}$ catalyst sample (from 476 to $348 \mathrm{~m}^{2} \mathrm{~g}^{-1}$ ). This decrease is accompanied with a parallel decrease in the main hydrolic pore radius (from $17.5 \AA$ to $16.5 \AA$ ). This may be attributed to the penetration process and the incorporation of $\mathrm{Ni}$ metal inside pores [32]. This is confirmed by pore size distribution of $\mathrm{BJH}$ method, where blocking of main pore radius at $r=17.5 \AA$. For loading >

$5 \mathrm{wt} . \% \mathrm{Ni}$, an increase in the surface area is observed (to $361 \mathrm{~m}^{2} \mathrm{~g}^{-1}$ ) with retaining the original pore radius at $r=17.5 \AA$ was observed (Fig. 2). However the total pore volume decreased gradually with loading, as a result of the penetration of $\mathrm{Ni}$ atoms into the silica pore system.

From the surface characteristics of $\gamma-\mathrm{Al}_{2} \mathrm{O}_{3}$ (Fig. 3) in relation to their Pt supported catalysts it was found that, the obtained $\mathrm{N}_{2}$ adsorption-desorption isotherms for $\gamma$ $\mathrm{Al}_{2} \mathrm{O}_{3}$ support and various $\gamma-\mathrm{Al}_{2} \mathrm{O}_{3}$ supported samples are of type II [32]. These isotherms are characteristic of macroporous material with $\mathrm{H} 3$ hysterses loop referred to plate like pores.

The data illustrated in Table 2 indicates that the specific surface area of pure $\gamma-\mathrm{Al}_{2} \mathrm{O}_{3}$ decreased by loading platinum particles (from 180 to $154 \mathrm{~m}^{2} \mathrm{~g}^{-1}$ for $0.6 \mathrm{wt}$. $\% \mathrm{Pt}$ ); the decrease being relatively slight by changing the Pt loading from 0.3 to $0.6 \mathrm{wt}$. \%. A parallel decrease is observed in $\mathrm{Vp}$ values. This may favour the penetration process of Pt particles in alumina pore system as evidenced from pore size distribution (Fig. 3 ). Mixed pore systems seem to be displayed. The distribution of the wider fraction of the mesopores for the $0.6 \mathrm{wt} . \% \mathrm{Pt}$, appears narrower than other samples, which may related to the above penetration phenomenon. 


\subsection{Catalytic activity of $\mathrm{Ni} /$ silica gel and $\mathrm{Pt} / \gamma$-alumina catalysts}

The pure silica gel support appeared inert in the studied reactions. The obtained samples became promising cracking catalyst showing pronounced activity even in lower temperature range, viz., $300-350^{\circ} \mathrm{C}$. All catalyst samples showed nearly $100 \%$ conversion and almost $100 \%$ selectivity for this temperature range (Fig.4). For npentane, the activity behaviour was almost the same for the different supported $\mathrm{Ni}$ samples, mainly cracking with some little isomerization activity. This phenomenon appeared with $2 \mathrm{wt} . \%$ sample, nickel seems to be enough to unbalance the charges in silica gel and the activation of $\mathrm{OH}$ groups leading to its cracking activity. It is known from literature that cracking takes place at stronger acid sites (Lewis acid sites) while isomerism takes place at moderate acid site (Brönsted acid sites). Cracking occurs predominantly at high temperature region while isomerization takes place at lower temperatures. The rise of reaction temperature enhances the temperature of (Brönsted acid sites) into the Lewis ones. The markedly low isomerizing activity shown in our cases at lower temperature range, suggests that supported Ni particles cover the weak- moderate acid sites of supported silica, leaving the strongest ones available for cracking process.

The catalytic activity towards benzene formation increased by increasing $\mathrm{Ni}$ content (Fig.5). In general the cracking activity seems to be predominantly due to the availability of strongest acid sites of silica support.

However, the dehydrogenation activity start to appear markedly for the sample of 8 $\mathrm{wt} \% \mathrm{Ni}$ where aggregation of $\mathrm{Ni}$ particles existing over weaker- moderate acid-sites takes place which favours of the dehydrogenation behaviour observed in the temperature region up to $330^{\circ} \mathrm{C}$. After this temperature, formation of propane, produced during homolytic cracking of cyclohexane, may then take place, achieving its maximum value at $420^{\circ} \mathrm{C}$ [21].

The catalytic conversion of $\mathrm{n}$-hexane over $\mathrm{Pt} / \mathrm{y}$-Alumina catalysts with different $\mathrm{Pt}$ loading (Fig. 6), gives rise to different types of reactions (e.g., cracking, isomerization, dehydrocyclization and cyclization) since many products are obtained. The yield of each of these reactions was quantitatively very small and increased slightly by increasing temperature and $\mathrm{Pt}$ loading. However, isomerization reaction to $\mathrm{C}_{6}$ isomers showed high selectivity in comparison with other reactions up to $330^{\circ} \mathrm{C}$ (Fig. 6).

The catalytic activity of $\mathrm{Pt} / \gamma-\mathrm{Al}_{2} \mathrm{O}_{3}$ in cyclohexane conversion was shown in (Fig. 7), where the total conversion increased by increasing the reaction temperature in the range $240-480^{\circ} \mathrm{C}$. Benzene yield (mole \%) increased sharply with temperature and reached $100 \%$ at $330^{\circ} \mathrm{C}$ for the sample containing $0.6 \mathrm{wt}$. \%, compared with that of $0.3 \mathrm{wt}$. \% Pt (85\%). The selectivity of benzene formation, reached $100 \%$ over the whole range of temperature (Fig. 7), being in line with zelinsky reaction [33]. This behaviour reflects that the activity of the catalyst for cyclohexane dehydrogenation 


\subsection{Electrical properties of $\mathrm{Ni} /$ silica gel and $\mathrm{Pt} / \gamma$-alumina catalysts}

Electrical measurements on the studied samples were carried out in the range of 0.1 $\mathrm{Hz}$ to $100 \mathrm{KHz}$ at room temperature $\left(\sim 20^{\circ} \mathrm{C}\right)$. Assuming that, $\mathrm{Ni}$ or Pt particles are optimally dispersed over the surface of the supports, this may give rise to electrical behaviour which differs from both constituents (host and guest; i.e. support and loaded metal). Materials studied herein are silica gel (host) loaded by (2, 5 and 8 wt. $\% \mathrm{Ni}$ ) and $\mathrm{y}$-alumina (host) loaded with $(0.3$ and $0.6 \mathrm{wt} . \% \mathrm{Pt})$. The electrical properties of the studied samples showed a dependence on metal content, i.e., the conductivity increases with the increase of metal content (Fig. 8 and 9) as well as the dielectric constant (Fig. 10 and 11). In the frequency domain studied of such systems, the frequency of the applied field was found to play an important role in the characterization of the system. The sample conductivity or dielectric constant showed a great dependence on the applied frequency. Such dependence is called dispersion.

Generally, the electrical conductivity and dielectric constant are directly related to the amount of free or bond charge carriers as well as their mobility. The ionic conduction of samples results from the migration of exchangeable cations along the channels and cavities of the grains according to an ion-hopping mechanism. The activation energy of ion hopping depends on the temperature, water content and conductor content (module) [12].

Catalytic reactions, involving surface hydroxyl groups, can change both the surface potential and concentration of point defects, which control electro-physical properties of poly- and nanocrystalline metal oxides.

Figure (8) shows the variation of the conductivity with frequency for silica gel supported nickel with different nickel loadings $(0,2,5$ and $8 \mathrm{wt} . \% \mathrm{Ni})$. The pure silica gel curve (zero wt. \% Ni) had a conductivity of nearly $6 \times 10^{-6} \mathrm{~S} / \mathrm{m}$ at $0.1 \mathrm{~Hz}$. The curve had nearly two slopes. At low frequency (up to $1 \mathrm{KHz}$ ) the conductivity showed nearly no dispersion with frequency (slope $\sim 0.03$ ). At high frequency (above $1 \mathrm{KHz}$ ) the sample conductivity showed a dependence on frequency (slope 0.5). For 2 wt. \% $\mathrm{Ni} /$ silica gel catalyst sample, the conductivity increased to nearly $9 \times 10^{-6} \mathrm{~S} / \mathrm{m}$ at 0.1 $\mathrm{Hz}$. The curve has nearly one slope $(\sim 0.38)$, which obeys the universal power law [34]. Also, by increasing $\mathrm{Ni}$ loadings (viz., 5 and $8 \mathrm{wt} . \% \mathrm{Ni}$ ) the value of the conductivity increased to $\sim 4 \times 10^{-5} \mathrm{~S} / \mathrm{m}$ at $0.1 \mathrm{~Hz}$ (for 8 wt. \% Ni catalyst) which indicates that the pure silica gel (support) is inert compared with silica gel loaded with nickel samples [35]. This may explain why parent silica gel support is catalytically dead towards n-pentane cracking pathways. The observed increase of conductivity with the increase in metal loadings may be governed by mixture laws [34,36-37] 
and/or mobility of charge carriers [38-39], giving rise to semiconductors like mechanisms in electronic circuits.

Figure (9) shows the variation of conductivity with frequency for $\gamma-\mathrm{Al}_{2} \mathrm{O}_{3}$ supported platinum with different $\mathrm{Pt}$ loadings $\left(0,0.3\right.$ and 0.6 wt. \%) where the $\gamma-\mathrm{Al}_{2} \mathrm{O}_{3}$ conductivity reached $8 \times 10^{-5} \mathrm{~S} / \mathrm{m}$ at $0.1 \mathrm{~Hz}$. The curve has two slopes. At low frequency (up to $1 \mathrm{KHz}$ ) the conductivity shows nearly no dispersion with frequency (slope $\sim 0.03$ ). At high frequency (above $1 \mathrm{KHz}$ ) the sample conductivity showed a dependence on frequency (slope 0.5). This may be also related to the inert behaviour of this support in the different catalytic reactions under study.

For 0.3 wt. $\% \mathrm{Pt}$, the conductivity increased to nearly $2 \times 10^{-6} \mathrm{~S} / \mathrm{m}$ at $0.1 \mathrm{~Hz}$. The curve had two slopes (as the $\gamma-\mathrm{Al}_{2} \mathrm{O}_{3}$ curve), which obeys the universal power law (Jonscher 1999) [34]. Also, with increasing $\mathrm{Pt}$ loadings (0.6 wt. \% Pt), the conductivity increased to $\sim 5 \times 10^{-6} \mathrm{~S} / \mathrm{m}$ at $0.1 \mathrm{~Hz}$. The observed increase in conductivity is in accordance with the increase of the catalytic activity [34, $37 \& 40]$ and/or mobility of charge carriers [37, 39, 17, 35].

It is known that $\mathrm{Pt}$ existing in very small atoms, behave as highly magnetized particles with super-high mobilization ability required for highly active catalytic agents. At low frequency $(<1 \mathrm{KHz})$ the behaviour of the conductivity may reflect production of charge carriers at the interfaces accompanied by transport of such charge carriers to reach measuring electrode and discharge there. At higher frequencies $(>1 \mathrm{KHZ}$ ) such charge carriers cannot reach the electrodes. These charge carriers are collected around grains and undergo local motion which gives rise to frequency dependence conductivity. By increasing metal content (Fig. 8 and Fig. 9) an increase in the production of charge carriers takes place with much transport of diffused charge carriers to reach electrodes and discharge there. Such process dominates all over the applied frequency range.

Figure (10) shows the variation of the dielectric constant with frequency of silica gelsupported nickel catalyst samples with different nickel loadings $(0,2,5$ and 8 wt. \% $\mathrm{Ni})$. It could be noticed that the silica gel has dielectric constant of nearly $3 \times 10^{5}$ at $0.1 \mathrm{~Hz}$. The curve has nearly two slopes; the first in the low frequency (up to $1 \mathrm{KHz}$ ) is very steep (slope -1). The second slope (above $1 \mathrm{KHz}$ ) is less steep $(\sim-0.5)$. For 2 wt. \% Ni/silica gel catalyst sample, the dielectric constant increased up to nearly $8 \times 10^{5}$ at $0.1 \mathrm{~Hz}$. The curve has only one slope which is nearly the same slope as the pure silica gel (support). Also, with increasing $\mathrm{Ni}$ loadings (5 and $8 \mathrm{wt}$. \% Ni) the value of the dielectric constant increased to be $\left(\sim 3 \times 10^{6}\right)$ at $0.1 \mathrm{~Hz}[40-42]$.

Balaya et al. (2004) [44] showed that silica containing relatively low concentrations of conductor materials exhibits relatively high dielectric constant (higher than calculated from mixture laws). It is likely to state that conducting constituents (Ni particles in our 
case) coats insulating base material (mainly the moderate Brönsted acid sites leaving the strongest acid ones) and electrostatic force arise at interfaces, giving rise to higher dielectric constant [41, 43-45].

Figure (11) shows the variation of the dielectric constant with frequency for $\gamma-\mathrm{Al}_{2} \mathrm{O}_{3}$ supported platinum catalyst samples with different Pt loadings (0, 0.3 and 0.6 wt. \%). It could be noticed that $\gamma-\mathrm{Al}_{2} \mathrm{O}_{3}$ has dielectric constant of nearly $6 \times 10^{4}$ at $0.1 \mathrm{~Hz}$. The curve has nearly two slopes, the first in the low frequency (up to $1 \mathrm{KHz}$ ) is very steep (slope -1). The second slope (above1 KHz) has gentle slope ( 0.33). With the increase of $\mathrm{Pt}(0.3 \mathrm{wt} . \% \mathrm{Pt})$ the dielectric constant increases to nearly $2 \times 10^{5}$ at $0.1 \mathrm{~Hz}$. With additional increase of loadings $(0.6 \mathrm{wt}$. \% Pt) the value of the dielectric constant increased to $\left(\sim 3 \times 10^{5}\right)$ at $0.1 \mathrm{~Hz}$. That increase in dielectric constant may be attributed to the decrease of the distance between grains [40, 41, 43].

In the low frequency range (lower than $1 \mathrm{KHz}$ ) the dispersion of the dielectric constant showed an inverse proportionality with the applied frequency (a straight line with a slope -1), which reflects diffusion of charge carriers to reach electrodes and discharge there. At higher frequencies $(>1 \mathrm{KHz})$ charge carriers had no time to reach electrodes. Its capacitance showed a little dependence on the applied frequency field. By increasing metal content in the measured samples (Fig. 10 and 11) the production of charge carriers increased. Diffusion mechanism dominates all over the applied frequency range $(0.1 \mathrm{~Hz}$ up to $100 \mathrm{KHz})$.

By increasing $\mathrm{Ni}$ or $\mathrm{Pt}$ loadings on $\mathrm{SiO}_{2}$ or $\mathrm{Al}_{2} \mathrm{O}_{3}$, some aggregate of metal particles took place (with less dispersion). i.e. less distance between supported particles being in accordance with the increase in dielectric constant and conductivity measurements. Finally from the above mentioned results, it could be concluded that the electrical conductivity increases with the applied frequency and which is in agreement with increasing of metal loading associated with increasing of catalytic activity and could present prior information about the catalytic activity of such catalysts.

\section{CONCLUSIONS}

- $\quad$ Pure silica gel and $\mathrm{y}-\mathrm{Al}_{2} \mathrm{O}_{3}$ supports were inert towards all reactions under study. They had relatively the lowest conductivity and dielectric constant values.

- By increasing $\mathrm{Ni}$ loadings the catalytic activity towards n-pentane cracking increased. 8 wt.\% Ni samples displayed promising dehydrogenation activity at $330^{\circ} \mathrm{C}$ after which it exhibited mainly cracking pathway. Such behaviour was also in good accordance with the increase of the conductivity and dielectric constant. The catalyst sample of $0.6 \mathrm{wt} . \% \mathrm{Pt} / \mathrm{y}-\mathrm{Al}_{2} \mathrm{O}_{3}$ was the most active and selective catalyst for cyclohexane dehydrogenation into benzene (100\% selective) among the catalyst samples studied. This was in good accordance with the increase of the conductivity and dielectric constant. 
- The increase of the conductivity and dielectric constant could be considered as a good indicator of the increase of charge carrier production and mobility. At low frequencies $(<1 \mathrm{KHz})$ the behaviour of the conductivity and dielectric constant might reflect the production of charge carriers at the interfaces (metal/support). At higher frequencies $(>1 \mathrm{KHZ})$ charge carriers has no time to reach the electrodes and accordingly collected around grains while undergo local motion.

- By increasing the metal content in the measured samples the production of charge carriers increased and the diffusion mechanism dominated all over the applied frequency range $(0.1 \mathrm{~Hz}$ up to $100 \mathrm{KHz})$. By increasing $\mathrm{Ni}$ or Pt loadings over $\mathrm{SiO}_{2}$ or $\mathrm{Al}_{2} \mathrm{O}_{3}$, some aggregate of metal particles took place (with less dispersion). i.e. less distance between supported particles being in accordance with the increase in dielectric constant and conductivity measurements, i.e. ions and free radicals taking part in the mechanism of catalytic conversion of hydrocarbons over the catalyst polarized active centers which increased by increasing metal loading.

\section{ACKNOWLEDGMENT}

The authors would like to express deep gratitude to Prof. Dr. F. H. Khalil, department of catalysis, Egyptian Petroleum Research Institute (EPRI) for his sincere supervision, constructive and valuable discussions.

The authors also like to express their thanks to Prof. Dr. S. A. Hussein, Department of Geophysics Science, National Research Center for his respective discussions of electrical measurments.

\section{REFERENCES}

[1] Burke, P. A. and Ko, E. I., "Propane Hydrogenolysis Over Supported Nickel Catalysts: Structural and Support Effects", J. Catal., Vol. 116, pp. 230 (1989).

[2] Areshidze, Kh. I. and Chivadze, G. O., Preparation of Catalysts, (Delmon, B.; Jacobs, P.A.; Poncelet, G. Eds.), Elsevier, Amesterdam (1976).

[3] Bruch, R. and Flambard, A. R.,"Reaction Specificity In Catalysts Reported To Exhibit Strong Metal-Support Interactions", React. Kinet. Catal. Lett., Vol. 17 No.(1-2), pp.23 (1981).

[4] Corma, A. and Mifsud, A., "Influence of The Procedure on Nickel Deposition on The Textural and Catalytic Properties of Nickel/Sepiolite Catalysts", Pérez Pariente J., Ind. Eng. Chem. Res., Vol. 27, pp. 2044 (1988).

[5] Nikolajenko, V., Bosáček, V., Daneš, VI., "Investigation of Properties of The Metallic Nickel Surface in Mixed Ni---MgO Catalysts", J. Catal., Vol. 2, pp. 127 (1963).

[6] Vannice, M. A. and Garten, R. L., "Metal-Support Effects on The Activity and Selectivity of Ni Catalysts in $\mathrm{CO} / \mathrm{H}_{2}$ Synthesis Reactions", J. Catal., Vol. 56, No. 2, pp. 236 (1979). 
[7] Taylor, W. F., Yates, D. J. C. and Sinfelt, J. H., "Catalysis over Supported Metals. II. The Effect of the Support on the Catalytic Activity of Nickel for Ethane Hydrogenolysis", J. Phy. Chem., Vol. 68, pp. 2962 (1964).

[8] Carrado, K. A. and Xu, L., "In Situ Synthesis of Polymer-Clay Nanocomposites from Silicate Gels", Chem. Mater., Vol. 10, No.5, pp.1440 (1998).

[9] Fukuka, A., Sakamoto, Y., Guan, S., Inagaki S., Sugimoto, N., Fukushima Y., Hirahara, K, lijima, S. and Ichikawa, M., "Novel Templating Synthesis of Necklace-Shaped Mono- and Bimetallic Nanowires in Hybrid Organic-Inorganic Mesoporous Material" J. Am. Chem .Soc., Vol. 123, No.14, pp. 3373 (2001) .

[10] Behrens, P., "Mesoporous inorganic solids", Adv. Mater., Vol. 5, No. 2, pp.127 (1993).

[11] Zhang, X., Zhang, F., and Chan, K.Y., "The Synthesis of Large Mesopores Alumina By Microemulsion Templating, Their Characterization and Properties as Catalyst Support", Materials Letters Vol. 58, No. (22-23), pp. 2872-2877 (2004).

[12] Kurzweil, H., Linder, H. P., Stern, W. L., and Pridgeon, A. M., "Comparative Vegetative Anatomy and Classification of The Diseae (Orchidaceae)", Bot. J.Linn. Soc., Vol. 117, p. 171 (1995).

[13] Gobara, H. M., M. Sc. Thesis, Physico-chemical Studies of Some Metal Heated Catalysts. Cairo University, Egypt (2002).

[14] Houalla, M. and Delmon, B., "Physicochemical Characterization and Reproducibility on Nickel Oxide Supported on a Wide Range of Silica-Alumia" J. Phys. Chem. Vol. 84, No.17, pp. 2128 (1980).

[15] Maschmeyer, T., "Derivatised mesoporous solids", Curr. Opin. Solid state Mater. Sci., Vol. 3, No.1, pp.71 (1998).

[16] Bond, G. C., Heterogeneous Catalysis, Oxford University Press, Oxford (1988).

[17] Caldararu, M., Postole, G., Hornoiu, C., Bratan, V., Dragan, M. and Ionescu, N.

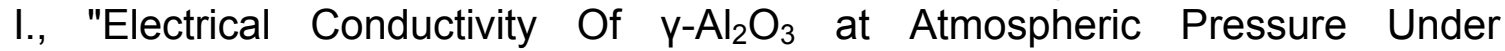
Dehydrating/Hydrating Conditions", Appl. Surf. Sci., Vol. 181, No. (3-4), P. 255, (2001).

[18] Gomaa, M. M. and Gobara, H. M." I. Electrical Properties of Ni/Silica Gel and Pt/ Y- Alumina Catalysts in Relation to Metal Content", (2007) in press.

[19] Voll'kenahtein, F.F., The Electroni Theory of Catalysis on Semiconductors, Pergamon Press, Oxford, London, New York (1963).

[20] Bahga, H. and Khalil, F. H., "Relation Between The Electrical Properties and Catalytic Activity of Some Egyptian Clays", J. surf. Technol., Vol. 17, p.61, (1982).

[21] Gobara, H. M., Ph.D. Thesis, Various Characteristics of Some Metal Loaded Catalyst for n-Paraffin's and Cycloparaffin's Conversion. Ain Shams University, Egypt (2006).

[22] Pinna, F., "Supported Metal Catalysts Preparation", Catal. Today, Vol. 41, P.129, (1998). 
[23] Beurther, H. and Larson, O. A., "Role of Catalytic Metals in Hydrocracking", Ind. Eng. Chem. Proc. Design Develop., Vol. 4, p. 177, (1965).

[24] Holm, V. C. F. and Clark, A., "Reduction studies on supported metal oxide catalysts", J. Catal., Vol. 11 ,pp. 305, (1968)

[25] Eischens, R. P., Preceedings of the Battelle Conference on surface Chemistry, Gastaad, Switzerland, (1974).

[26] Bournoville, J. P., Frank, J. P. and Martino G., "Preparation of Catalysts III", (Ponncelete G., Grange O. and Jacobs P., Eds.), Elsevier, Amsterdam, (1983).

[27] Zou, W. Q. and Gonzalez, R. D. "Thermal Stability of Silica Supported Palladium Catalysts Prepared by The Sol-Gel Method" Appl. Catal. A: Gen, Vol. 126, pp. 351, (1995).

[28] Lowell, S. and Shields, J. E., Powder Surface Area and Porosity, Third Ed., Chapman and Hall, (1991).

[29] Gomaa, M. M., Frequency Response Study on Iron Ore Bearing Rock Samples, M. Sc., Thesis, Cairo University, Egypt, (1996).

[30] Nettelblad, B. and Niklasson, G. A., "The Dielectric Dispersion of Liquid-Filled Porous Sintered Materials", J. Phys.: Condens. Matter, Vol. 8, pp. 2781, (1996).

[31] Šolcová, O. and Vit, Z., "Synthesis and Properties of Mesoporous SilicaAlumina with Narrow Pore Size Distribution Obtained Without Use of PoreRegulating Agents", Micro porous and Mesoporous Materials Vol. 96, pp. 197, (2006).

[32] Leofanti, G., Padovan, M., Tozzola, G. and Venturelli, B., "Surface Area and Pore Texture Catalysts", Catal. Today, Vol. 41, pp. 207, (1998).

[33] Zelinesky N. D., "Collective Scientefic Works", Published by Acadimic of USSR, p. 462-572, (1955).

[34] Jonscher, A. K.,"Dielectric Relaxation in Solids", J. Phys. D: Appl. Phys., Vol. 32, pp. 57, (1999).

[35] Kreuer, K. D., Dippel, Th., Haynovsky N. G., and Maier J., "Proton Conductivity: Compounds and Their Structural and Chemical Peculiarities", Ber. Bunsenges. Phys. Chem., Vol. 96, pp. 1736 (1992).

[36] Gomaa, M. M., Hussain, S. A. El- Diwany E. A., Bayoumi A. E. and Ghobashy M., "Renormalization Group Modeling Of A C Electrical Properties Of Natural Hematitic Sandstone Including Texture Effects", presented at the $69^{\text {th }}$ Annual International Meeting: Society of Exploration Geophysics (SEG) and International Exposition, Session "Borehole/Rock Physics characterization of rock and fluid properties", Oral PHRP7, Oct. 31- Nov. 5, Houston, Texas, pp.204, (1999).

[37] Soled S., " $\mathrm{Y}-\mathrm{Al}_{2} \mathrm{O}_{3}$ viewed as a defect oxyhydroxide", J. Catal., Vol. 81, pp. 252, (1983).

[38] Chelidze, T., and Gueguen, Y., "Electrical Spectroscopy of Porous Rocks: A Review -I. Theoretical Models", Geophys. J. Int., Vol. 137, p. 1, (1999). 
[39] Chelidze, T., Gueguen, Y. and Ruffet C., "Electrical spectroscopy of porous rocks: a review -II. Experimental results and interpretation", Geophys. J. Int., Vol. 137, p. 16, (1999).

[40] Gomaa, M. M., Darwish H, and Salman S. M., " Electrical properties of some $\mathrm{Y}_{2} \mathrm{O}_{3}$ and/or $\mathrm{Fe}_{2} \mathrm{O}_{3}$-containing lithium silicate glasses and glass-ceramics", J. of Mater. Sci.: Materials in Electronics, Vol. 19, pp. 5-15, (2008).

[41] EL-Desoky, M., "Dielectric Behavior and Ac Conductivity of Sodium Borate Glass Containing CoO", J. Phys. Chem. Solids, Vol. 59, No.9, pp. 1659 (1998).

[42] Dukhin, S. S., and Shilov V. N., "Dielectric Phenomena and The Double Layer in Disperse Systems and Polyelectrolytes", (John Wiley and Sons, Eds.) New York (1974).

[43] Zaky, A. A., and Hawley, R., "Dielectric solid", Routledge and Kegan Paul Ltd, London, pp. 37 (1970).

[44] Balaya, P., Shrikhande,V. K., Kothiyal G. P., and Goyal P. S., "Dielectric and Conductivity Studies on Lead Silicate Glasses Having Mixed Alkali and Alkaline Earth Metal Oxides", Curr. Sci., Vol. 86, pp. 553, (2004).

[45] Patel, H. K. and Martin, S. W., "Fast Ionic Conduction in $\mathrm{Na}_{2} \mathrm{~S}+\mathrm{B}_{2} \mathrm{~S}_{3}$ Glasses: Compositional Contributions To Nonexponentiality in Conductivity Relaxation in The Extreme Low Alkali-Metal Limit", Phys. Rev. B, Vol. 45, pp.10292, (1992). 


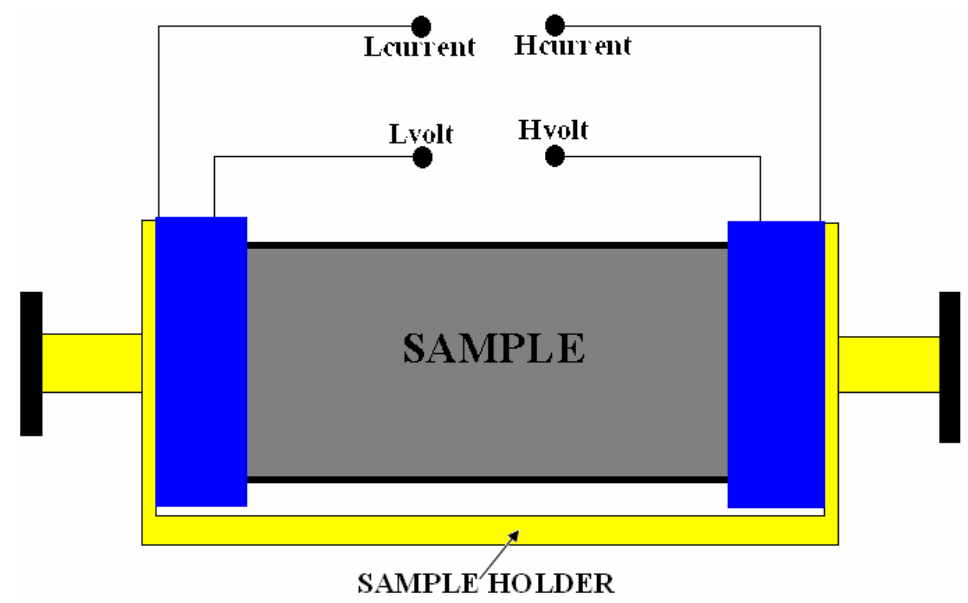

Fig. 1: Schematic representation of the sample holder used for the measurements. 

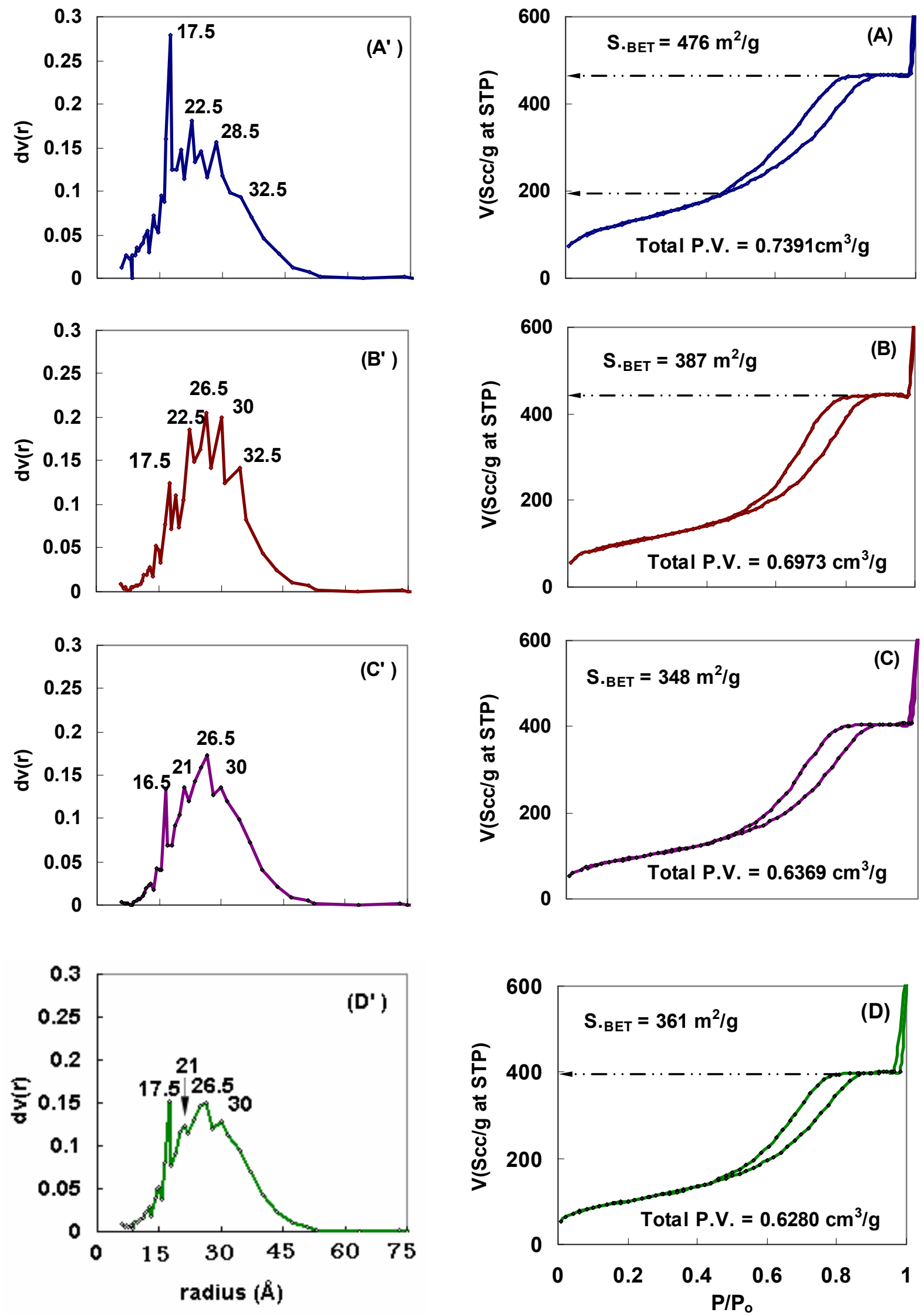
Fig. 2: Pore size distribution and isotherms for silica gel $(A)$ and nickel/silica gel catalysts with different nickel loading; 2 wt. \% Ni (B), 5 wt. \% Ni (C) and 8 wt. \% $\mathrm{Ni}(\mathrm{D})$.

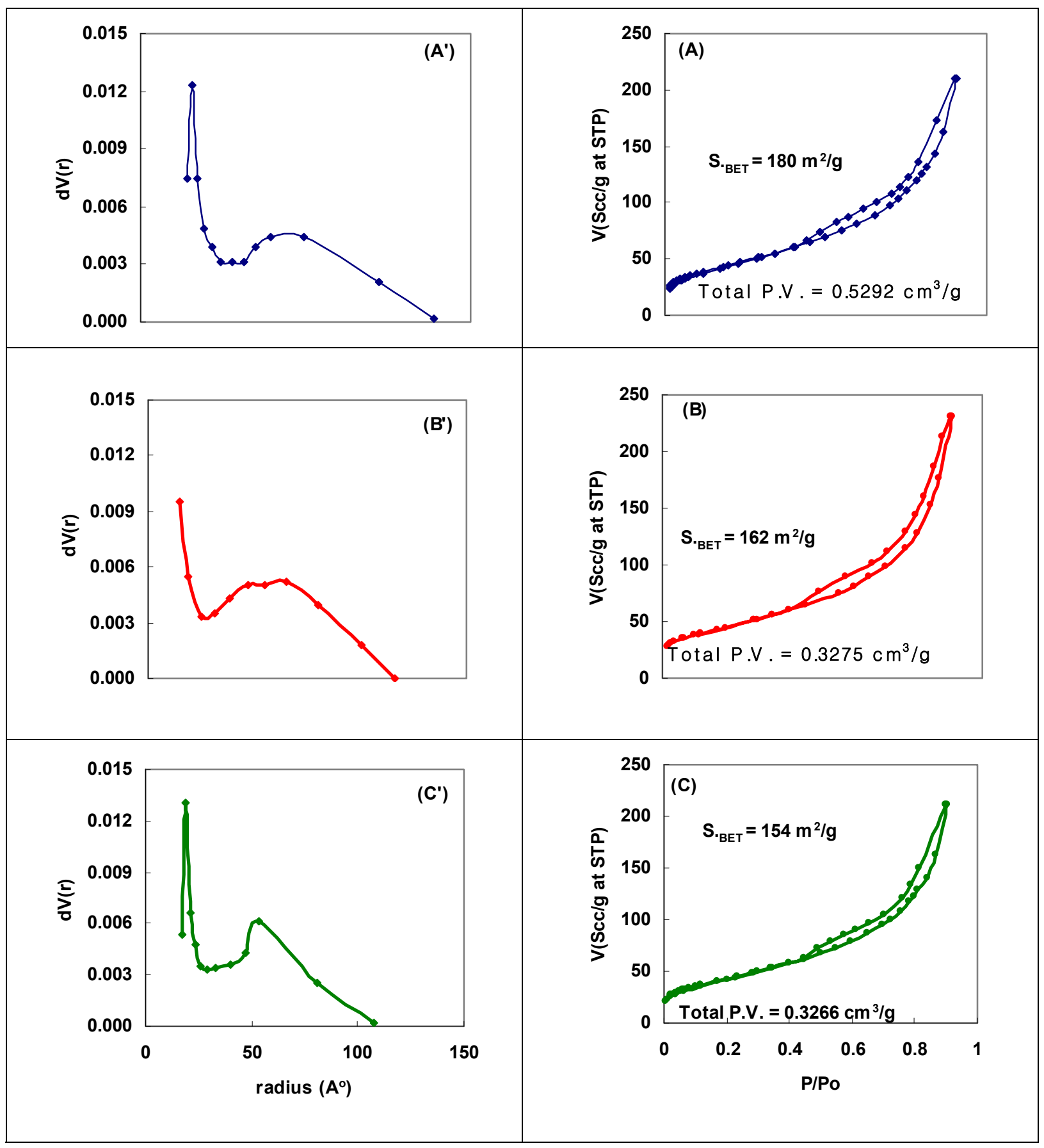

Fig 3: Pore size distribution and isotherms for alumina and $\mathrm{Pt}$ / alumina catalysts with different platinum loadings: 0.3wt.\% (B) and 0.6 wt. \% (C). 

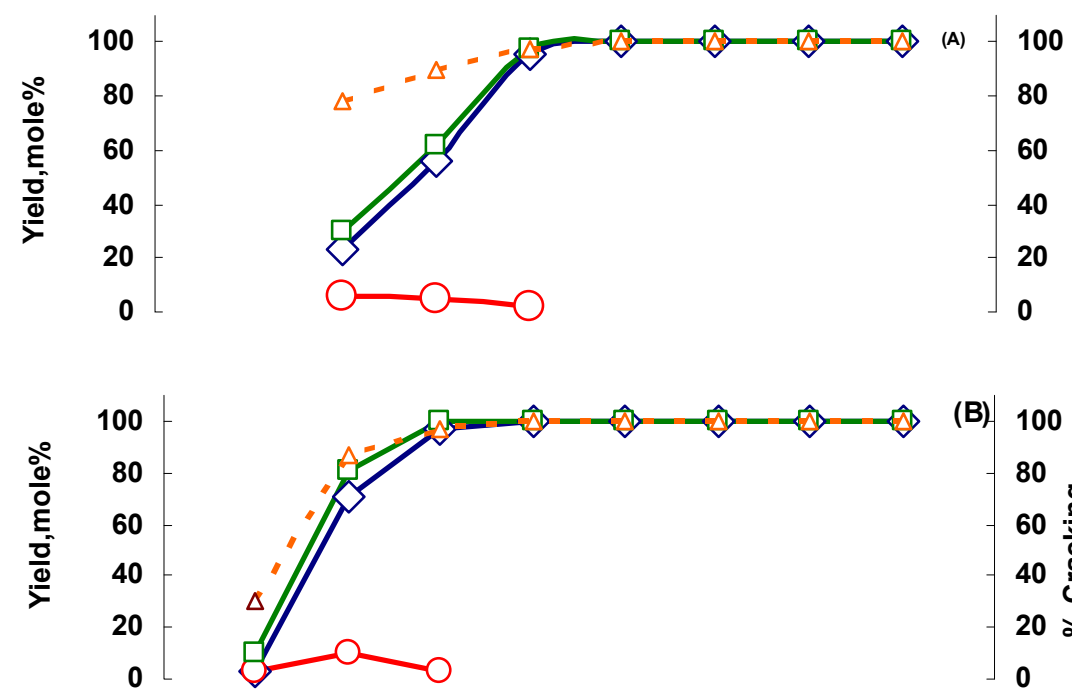

(B) 100
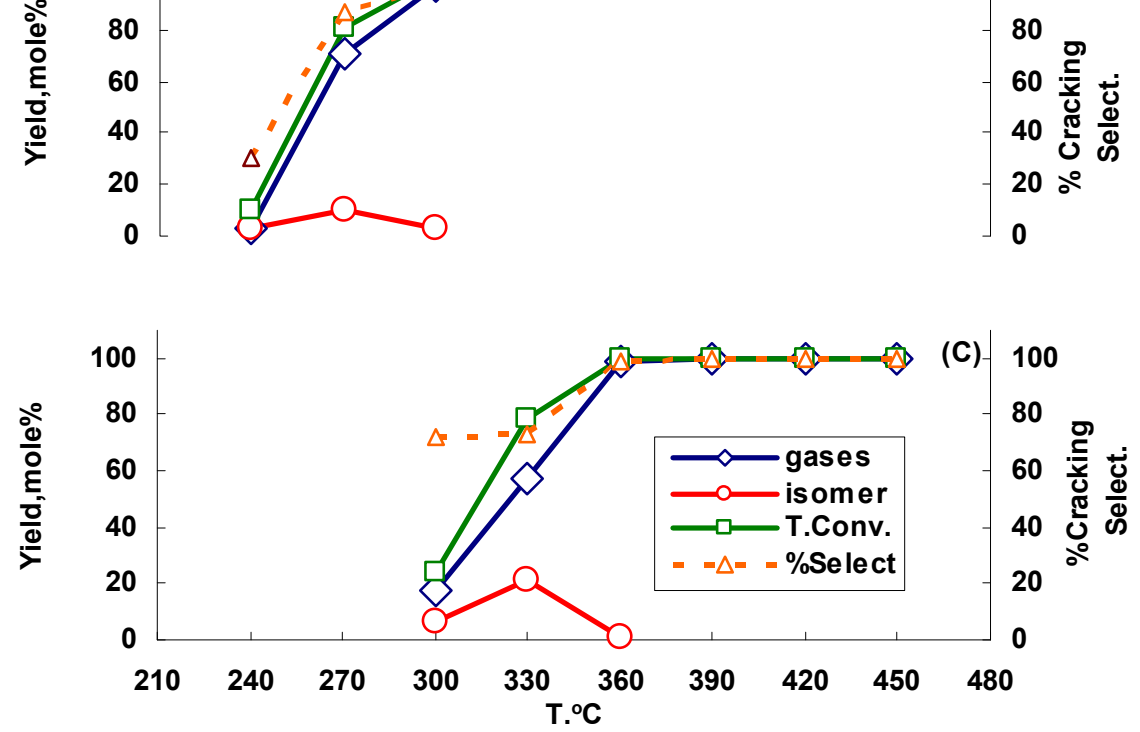

Fig. 4: Catalytic conversion of n-pentane over nickel/silica gel catalysts of different $\mathrm{Ni}$ loadings: $2 \% \mathrm{Ni}(\mathrm{A}), 5 \% \mathrm{Ni}(\mathrm{B})$ and $8 \% \mathrm{Ni}(\mathrm{C})$. 

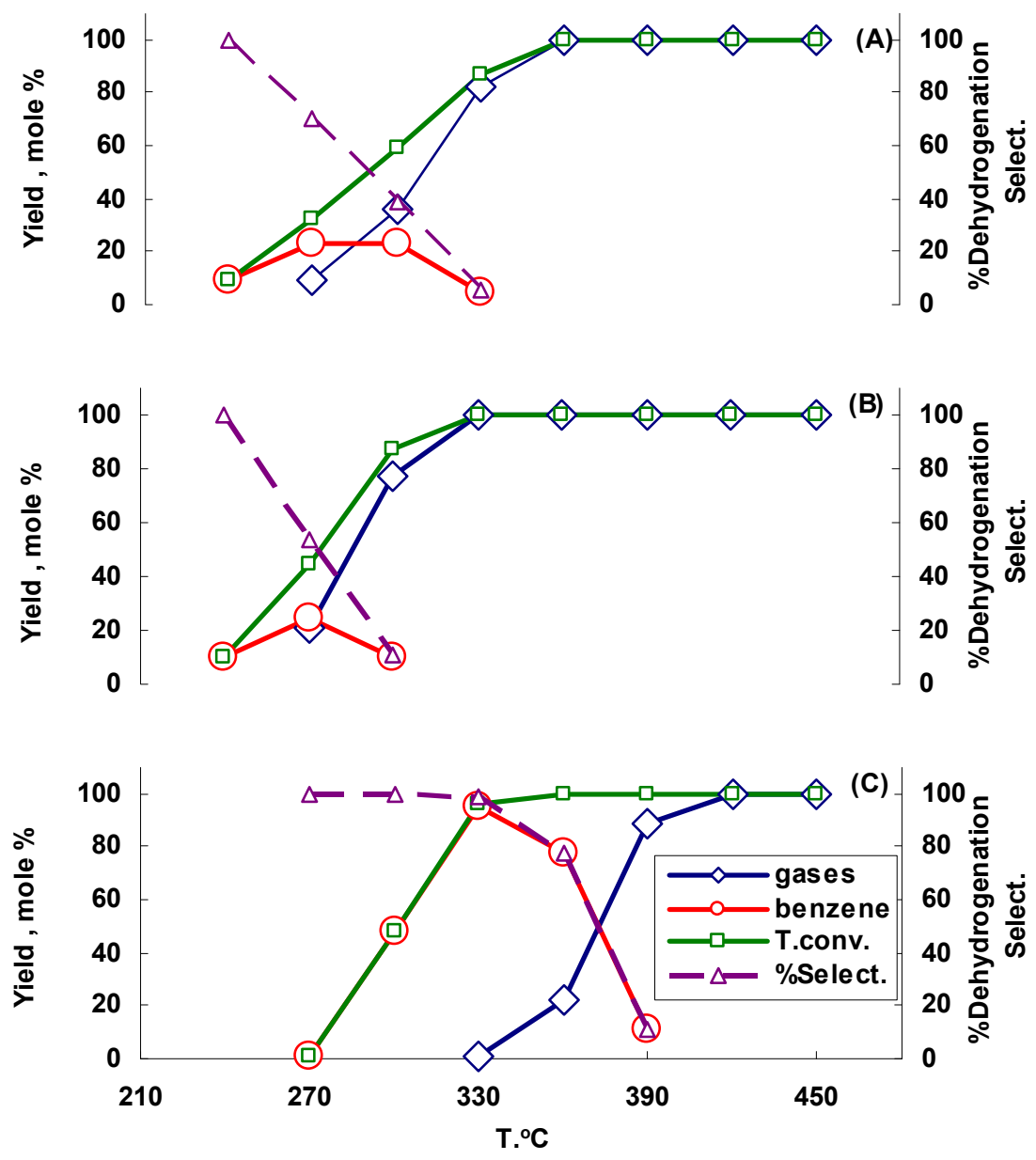

Fig. 5: Catalytic conversion of cyclohexane over nickel /silica gel catalysts with different nickel loadings: $2 \% \mathrm{Ni}(\mathrm{A}), 5 \% \mathrm{Ni}(\mathrm{B})$ and $8 \% \mathrm{Ni}(\mathrm{C})$. 


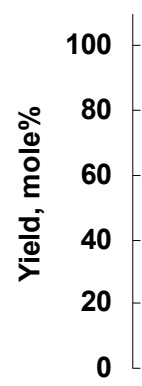

(A)

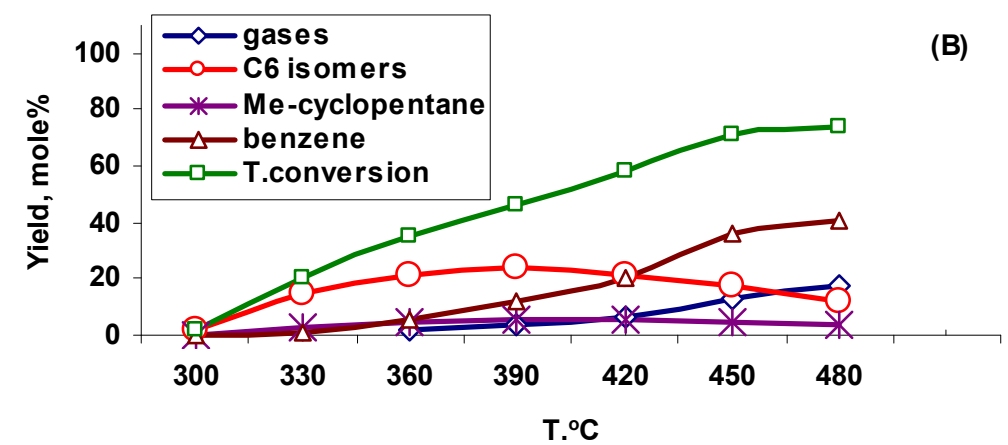

Fig. 6: Catalytic conversion of $n$-hexane over Pt/ $y$-Alumina catalysts: $0.3 \% \mathrm{Pt}(\mathrm{A})$ and $0.6 \% \mathrm{Pt}(\mathrm{B})$. 

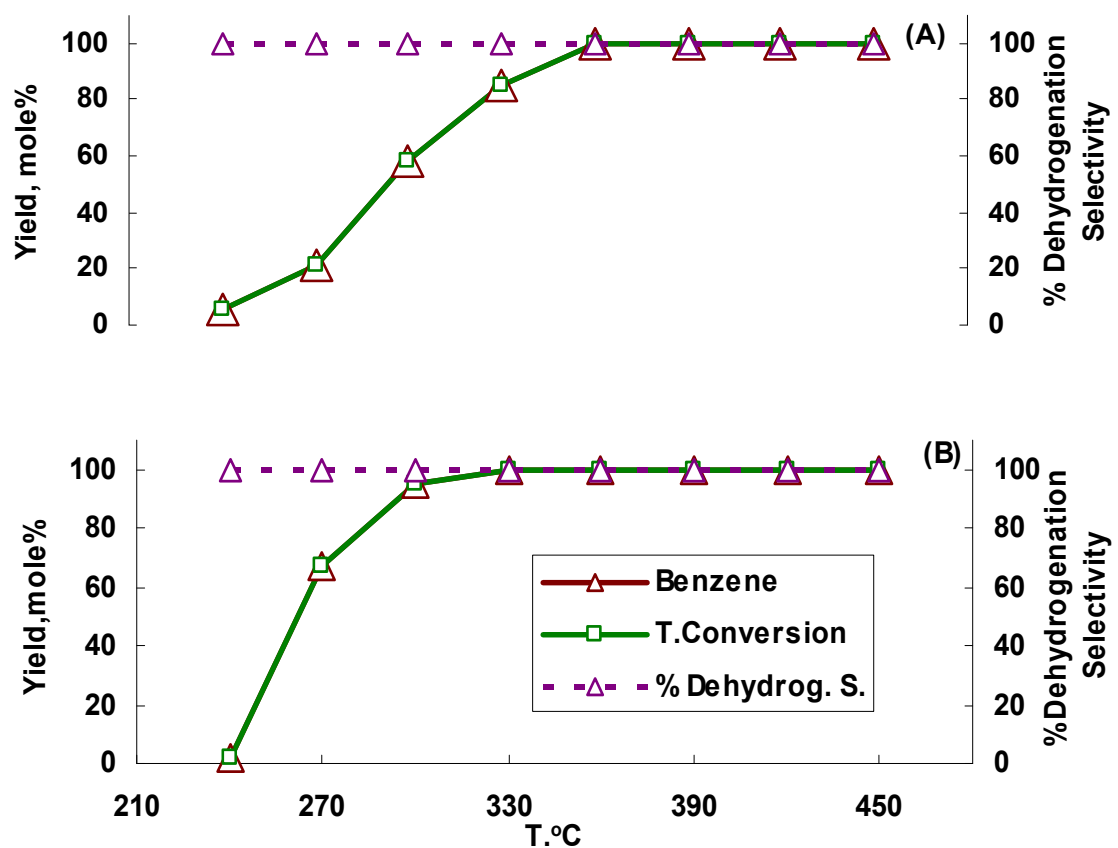

Fig. 7: Catalytic conversion of cyclohexane over Pt/ $\mathrm{Y}$-Alumina catalysts:

$0.3 \% \mathrm{Pt}(\mathrm{A})$ and $0.6 \% \mathrm{Pt}(\mathrm{B})$. 


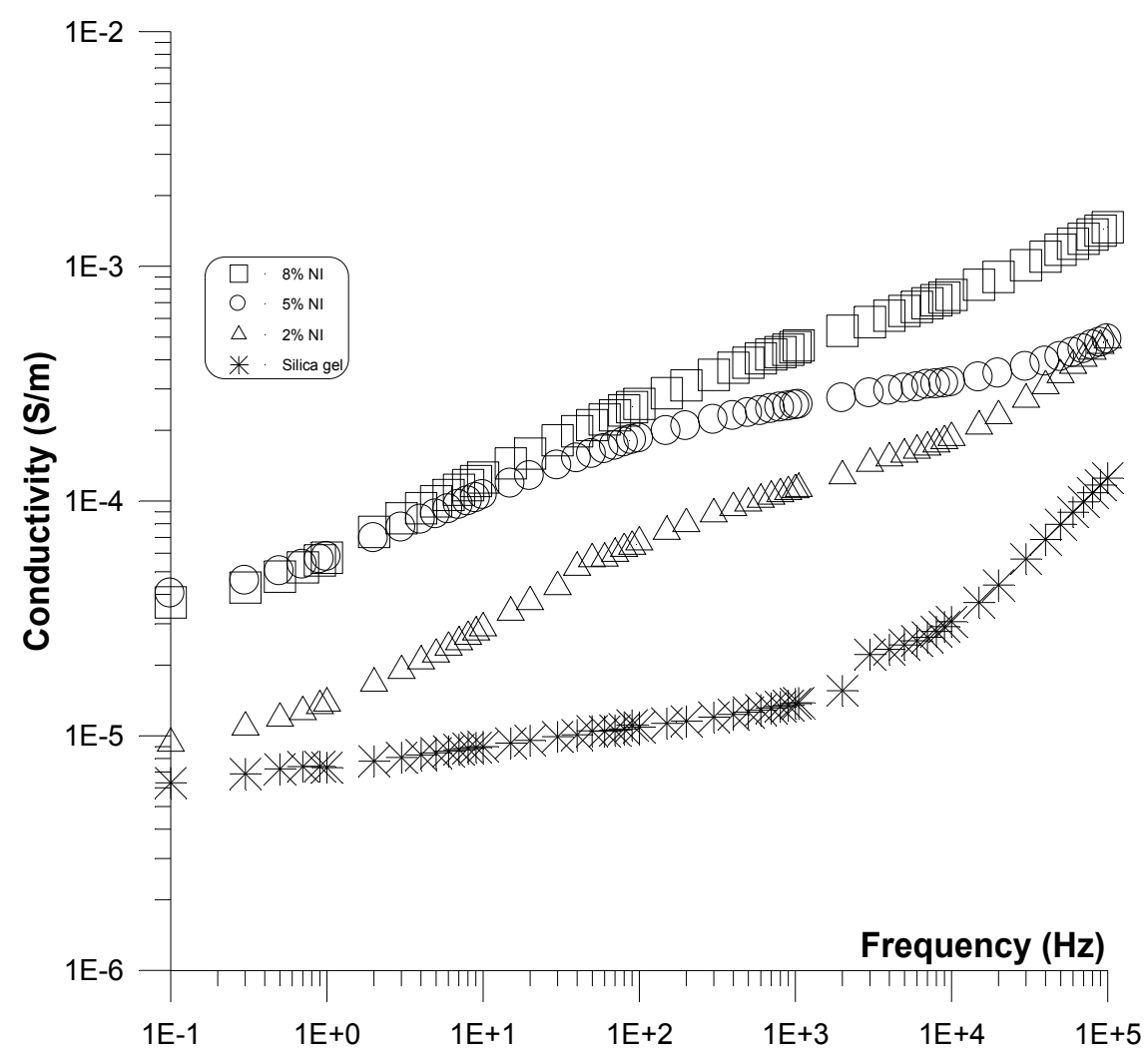

Fig. 8: The variation of the conductivity with frequency for silica gel (support) and silica gel supported nickel with different nickel loadings $(2,5$ and $8 \mathrm{wt}$. \% Ni). 


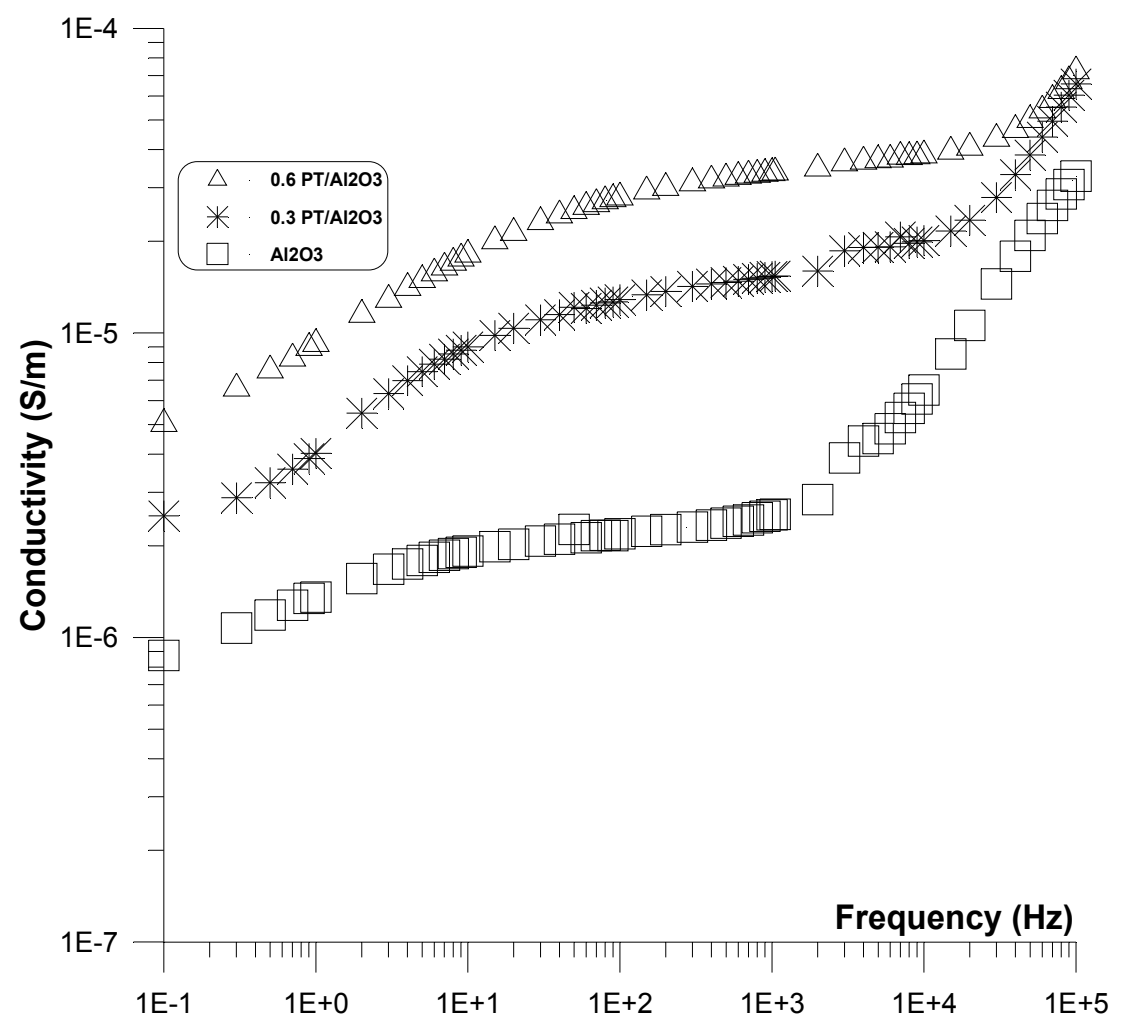

Fig. 9: The variation of the conductivity with frequency for $\gamma$-Alumina (support) and $\gamma$-Alumina supported Platinum with different Pt loadings (0.3 and 0.6 wt. \% Pt). 


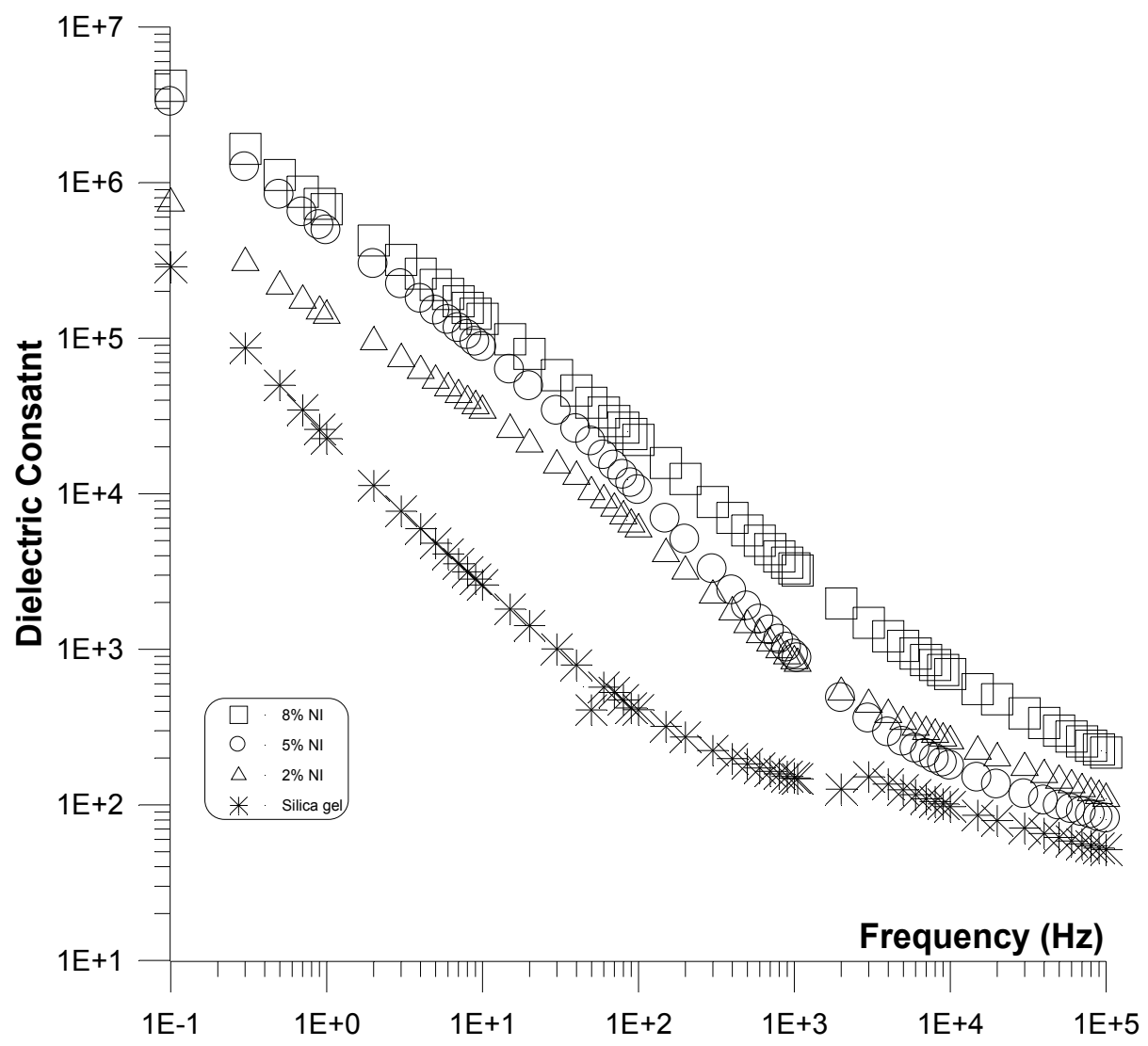

Fig. 10: The variation of the dielectric constant with frequency for silica gel (support) and silica gel supported nickel with different $\mathrm{Ni}$ loadings $(2,5$ and $8 \mathrm{wt}$. \% Ni). 


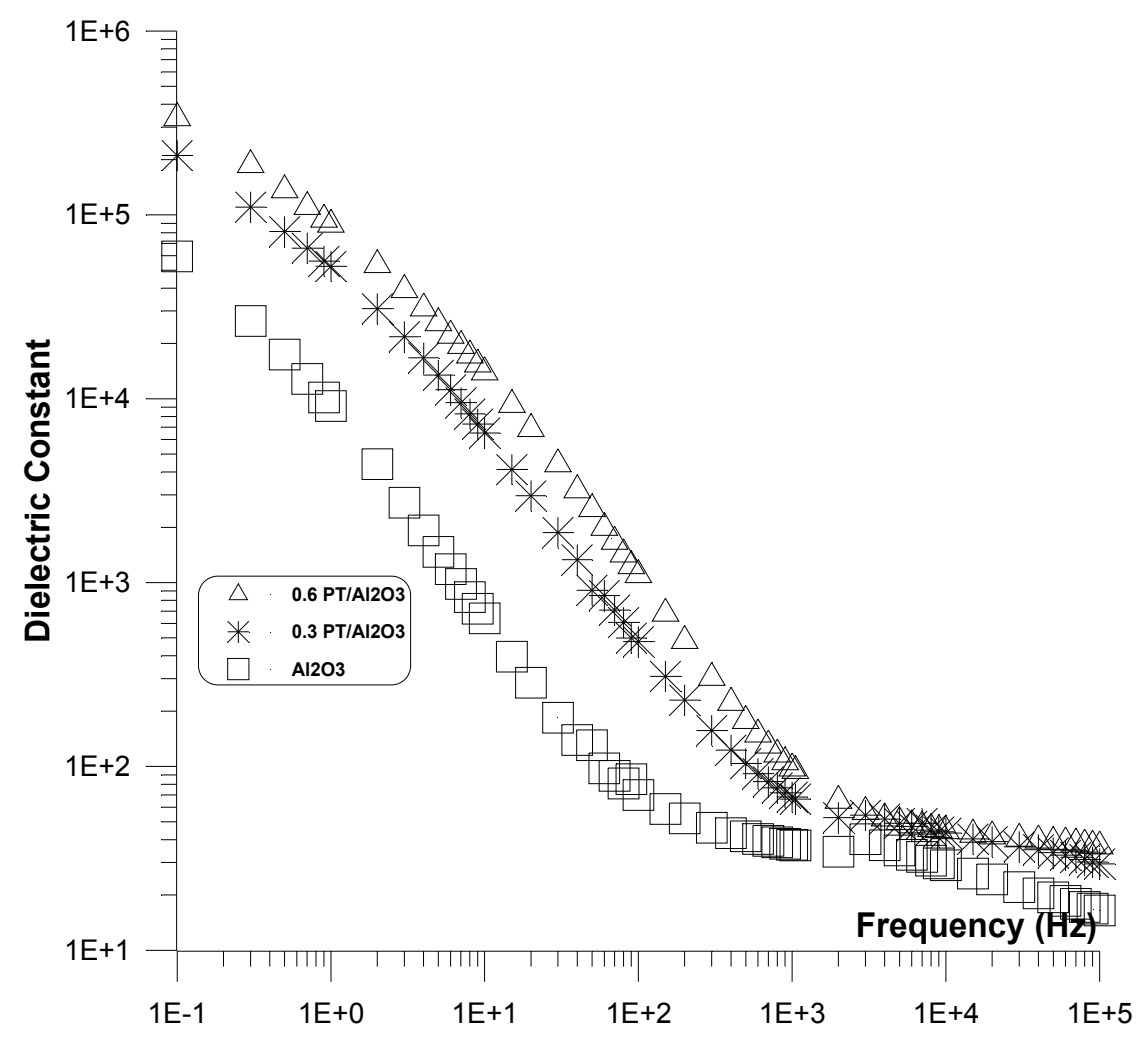

Fig. 11: The variation of the dielectric constant with frequency for $\gamma$-Aumina and $\gamma$-Alumina supported Platinum with different Pt loadings ( 0.3 and $0.6 \mathrm{wt}$ \% Pt). 
Table 1: Surface characteristics of Ni/Silica gel catalysts

\begin{tabular}{|c|c|c|}
\hline Catalyst name & $\left(S_{B E T}, m^{2} \mathrm{~g}^{-1}\right)$ & $\left(\mathrm{V}_{p}, \mathrm{Cm}^{3} \mathrm{~g}^{-1}\right)$ \\
\hline Silica gel (support) & 476 & 0.7391 \\
\hline $2 \% \mathrm{Ni} /$ Silica gel & 387 & 0.6973 \\
\hline $5 \% \mathrm{Ni} /$ Silica gel & 348 & 0.6369 \\
\hline $8 \% \mathrm{Ni} /$ Silica gel & 361 & 0.6280 \\
\hline
\end{tabular}

Table 2: Surface characteristics of $\mathrm{Pt} / \gamma$-Alumina Catalysts

\begin{tabular}{|c|c|c|}
\hline Catalyst name & $\left(S_{B E T}, m^{2} \mathrm{~g}^{-1}\right)$ & $\left(V_{p}, \mathrm{Cm}^{3} \mathrm{~g}^{-1}\right)$ \\
\hline$\gamma-\mathrm{Al}_{2} \mathrm{O}_{3}$ (support) & 180 & 0.5292 \\
\hline $0.3 \% \mathrm{Pt} / \gamma-\mathrm{Al}_{2} \mathrm{O}_{3}$ & 162 & 0.3275 \\
\hline $0.6 \% \mathrm{Pt} / \gamma-\mathrm{Al}_{2} \mathrm{O}_{3}$ & 154 & 0.3266 \\
\hline
\end{tabular}

